Ss. Cyril and Methodius University in Skopje

k.veljanovska@gmail.com

ORCID: 0000-0002-7230-5634

Биљана Мирчевска-Бошева

Ss. Cyril and Methodius University in Skopje biljana.mirchevska@gmail.com

ORCID: 0000-0001-9146-8538

\title{
Фраземи со зоонимна компонента од фразеосемантичкото поле 'време' во македонскиот јазик
}

\begin{abstract}
Veljanovska Katerina, Mirchevska-Bosheva Biljana, Frazemi so zoonimna komponenta od frazeosemantichkoto pole 'vreme' vo makedonskiot jazik (Zoonymic Phrasemes Denoting Time in Macedonian Language). "Poznańskie Studia Slawistyczne" 20. Poznań 2021. Publishing House of the Poznań Society for the Advancement of the Arts and Sciences, Adam Mickiewicz University, pp. 37-50. ISSN 2084-3011.

This article analyses Macedonian phrasemes with zoonymic component denoting time. Zoonyms mainly came from surrounding environment which was expected having in mind the fact that man often reaches for something that is well known to him in an attempt to understand something far and abstract, such as the category of time. What distinguishes the analyzed units from the rest of the phraseological material with zoonymic components is their relative neutrality, bearing in mind that in general the zoonymic phrases are negatively colored. Such neutrality is due to their semantics, as well as to the fact that they show the characteristics and animals behavior as they are in reality.
\end{abstract}

KeYwords: zoonyms; time; weather; Macedonian phraseology

\section{Вовед}

Човековиот и животинскиот свет се испреплетуваат на различни нивоа: од емпириско кое подразбира нивна меѓусебна зависност (човекот ги одгледува и ги чува животните како извор на храна и облека, заштита, помош во работата, за друштво и забава) до симболично кое вклучува нивна митологизација, фолклоризација, па дури 
и литераризација од страна на човекот (Vidović Bolt, 2011, 20; Новокмет, 2016, 26). За континуираниот соживот меѓу овие два света зборува и фактот дека животните биле почитувани во предисториските времиња, тие стануваат зооморфни богови во Стариот Египет, а подоцна и придружници на божества од грчката и римската митологија, како и на светците во христијанските хагиографски текстови. Тие биле инспирација за алегориски басни во кои им припишувале некои човечки карактеристики, а суеверијата од нив направиле носители на среќа или несреќа (Pamies, 2012, 293).

Присутноста на животните во секојдневниот живот, како и значајноста на улогата која ја имаат во животот на човекот се рефлектира и во јазикот, па така тие се често предмет на семантичка, ономастичка, компаративно-контрастивна, социолингвистичка и фразеолошка анализа. Имајќи го предвид фактот дека различните лингвистички дисциплини им приоѓаат на животните од различни аспекти, очекувано е и толкувањата значајно да се разликуваат. Овде би се повикале на Љубичиќ (Ljubičić, 1994, 245-246) кој зборувајќи за дефинирање на животните во толковните еднојазични речници нагласува дека честопати тоа се сведува на опис поткрепен со латинскиот назив (четвороножен цицач, домашно животно Canis familiaris) без да се опфатат преносните значења. Но, со издвојувањето на карактеристичните особини на животните, тие често се доведуваат во врска со човекот, со одредени предмети или појави. Така настануваат бројни споредби, метафори и метонимиски измени во значењето. За илустрација наведува дека кучето во фраземите добива значење: верност, макотрпна работа, осаменост, глад и сл.

Ова беше непосредна мотивација да ги разгледаме називите на животните фокусирајќи се на значењето кое го добиваат во составот на фразеолошките единици. Имајќи го предвид ограничувањето на обемот на трудот, за оваа прилика решивме да ги анализираме фраземите со зоонимна компонента кои припаѓаат на семантичкото поле време.

\section{Фраземи со зоонимна компонента}

Фраземите со зоонимна компонента претставуваат значаен сегмент од општиот фразеолошки фонд. Во овие единици зоонимната 
компонента како резултат на фразеологизацијата добива посебни, несистемски значења кои се несвојствени за зборовите во слободна употреба и можат да бидат идентификувани само при разложување на фразеолошкото значење (Мелерович, 1979, 79). Во таков случај зоонимот добива нова функција на актуелизација на најкарактеристичните, од гледна точка на човекот, својства на животните: начинот на движење, начинот на живот, однесувањето, надворешниот изглед, звуци и сл. При образувањето на значењето на фраземата тие семи се трансформираат во семи кои изразуваат нови, други признаци и својства на човекот. Во тој процес покрај мотивираноста од непосредното искуство, важна улога имаат и наталожените конотативни слоеви и културолошки стереотипи. Имено, овој сегмент од фразеолошкиот фонд укажува на силна антропоцентричност ${ }^{1}$, животните се разгледуваат преку човечкиот систем на вредности и навики врз кои влијаат традицијата, верата и просторот, односно фраземското значење се гради врз основа на добро познати и затврдени стереотипи за животните. Притоа, ним сосема неоправдано им се припишуваат одредени карактеристики или погрешно се толкува нивното однесување, а се смета дека причината за тоа е тоа што човекот поаѓа од себе во припишувањето на значењата (Макаријоска, Павлеска-Георгиевска, 2020, 182-183).

Голем број од фраземите со зоонимна компонента имаат целосни или делумни еквиваленти во другите јазици што се објаснува со совпаѓање на менталната слика на реалноста кај носителите на различни јазици и со заедничките елементи на културата - т.н. „културни универзалии“ (Телия, 1986, 91). Но, како резултат на различни културни фактори, етнички особености, различни јазични слики на светот и различни литературни извори, многу зооними содржат елементи на значењето кои се разбирливи само за носителите на дадената лингвокултура.

${ }^{1}$ Од вкупно 1041 фразема со зоонимна компонента во македонскиот јазик дури 949 $(91,16 \%)$ се антропоцентрични (Томоска, 2015, 16). 


\section{Концептот време}

Времето претставува нераскинлив атрибут на постоењето на сите предмети и процеси во материјалниот свет, важен сегмент на животот и сознанието на човекот, универзална категорија која секогаш предизвикувала интерес и била предмет на анализа на научниците од различни области.

Во теоријата се издвојуваат два основни модели за времето кои им се познати на луѓето уште од древни времиња: 1) цикличниот кој подразбира повторување на еднотипни настани и 2) линеарниот со значење на еднонасочно постепено движење.

Јаковлева (Яковлева, 1994) пишува дека во културната парадигма на носителите на јазикот со сфаќањето за цикличноста на времето се поврзува идејата за природните циклуси и бесконечните повторувања на едни и исти настани, а со сфаќањето за линеарното движење се поврзуваат карактеристиките: неповторливост, уникатност, единственост на настаните, неповторливост на животниот процес. Според тоа доаѓаме до заклучок дека цикличната претстава е насочена кон типизација, а линеарната кон индивидуализација.

Толстој (Толстой, 1997), пак, смета дека претставата за цикличноста на времето, за повторливоста на циклусот е карактеристична не само за словенскиот и за индоевропскиот етнос, туку и за сите народи од светот. Таа е универзална затоа што има екстрајазичен, екстрапсихолошки, екстрачовечки основи - таа е поврзана со природата, со вртењето на Сонцето околу Земјата. И ако затворениот круг на деноноќието и годината е исклучиво природна појава, тогаш делењето на тие кругови на делови, на периоди е дело на умот и искуството на човекот. Може да се забележи дека делењето на деноноќието на ден и ноќ е чисто природна појава, а јазикот само го фиксира и означува и дека подеталните поделби на деноноќието и на годината се во зависност од човечкото сознание.

Посебно внимание привлекува и фактот дека човекот нема орган специјализиран за восприемање на времето, а сепак го чувствува истото (Арутюнова, 1997). Во однос на тоа се поставува прашањето кои начини и механизми ги користи човекот за одредување и мерење на времето. 
Овој сложен ментален поим ја покажува својата многуслојна структура и во објаснувањето на лексемата време во Толковниот речник на македонскиот јазик (Конески, 2003, 307-308) каде се наведени 8 значења: 1. (само едн.) една од двете (покрај просторот) основни форми на постоење на материјата; 2. (само едн.) траење на нешто што се случува или што постои (мерено со секунди, минути, часови, денови итн.); 3. соодветен период, рок во којшто треба нешто да се збидне; 4. период од историјата, период поврзан со името на некоја личност; 5. доба, период од денот, од годината; 6. метеоролошка состојба; 7. граматичка категорија со која се определува глаголското дејство во однос на моментот на говорењето и 8. резултат во некои спортски дисциплини.

\section{Дефинирање на корпусот}

Фраземите со зоонимна компонента во македонскиот јазик предизвикуваат жив интерес кај истражувачите кој е актуелен и до ден денес за што сведочат истражувањата на Кузмановска и Петковска (2013), Велјановска (2014), Томоска (2015), Алчевска (2016), Макаријоска и Павлеска-Георгиевска (2020) и др. Во овие студии најчесто се обработуваат фраземи кои служат за опис на надворешниот изглед на човекот, неговите карактерни и интелектуални особини, чувства и емоции и сл. Ние во овој труд решивме да се фокусираме на фраземите кои означуваат време, како сегмент од македонската зоонимна фразеологија на кој претходно не му е посветено поголемо внимание.

Материјалот кој се анализира во овој труд е ексцерпиран од Фразеолошкиот речник на македонскиот јазик (2003-2009) на Тодор Димитровски и Ташко Ширилов, Македонска фразеологија со мал фразеолошки речник (2008) на Снежана Велковска, како и од статиите и прилозите на оваа тема.

Под фраземи со зоонимна компонента во овој труд поразбираме фраземи кои содржат најмалку еден назив на животно или придавски форми изведени од називот. Во анализираниот материјал не влегуваат фраземите кои содржат хипероним животно/стока, како и лексемите кои означуваат дел од телото на животно. На анализа подлежат 
единиците кои означуваат време (како една од основните форми на постоење на материјата), траење на нешто што се случува или што постои, соодветен период, рок во којшто треба нешто да се збидне, период од денот или од годината и метеоролошка состојба.

\section{Анализа на издвоениот материјал}

Од вкупниот фонд фраземи со зоонимна компонента кој вклучува 1040 единици само 19 припаѓаат на фразеосемантичкото поле време. Во составот на овие единици влегуваат 13 зооними: волк, гавран, глувче, гуштер, зајак, змија, куче/пес, кокошка, коњ, мечка, мачка, петел, риба и од нив изведените придавки: кучешки, петлен, петлина и свински.

Анализата ја започнуваме со фраземите кои означуваат дел од денот. Во нив доминира лексемата петел која во Дигиталниот речник на македонскиот јазик се дефинира како: 1. мажјак од кокошка; 2. (мн. петли) пеење на петлите доцна ноќе или рано наутро како знак за определено време од ноќта; 3. во шала за маж (ирон.); 4. калауз. Од наведените значења, за ова истражување го издвојуваме второто, т.е. определувањето на времето според пеењето на петлите. Тоа е мотивирано од однесувањето на оваа птица која се одликува со беспрекорен биолошки часовник и исклучителна сензитивност на светлината. Првото огласување на петелот се нарекува „први петли“ и тоа го најавува изгрејсонцето. Подоцна следат и други огласувања познати како втори, трети итн. петли. Токму затоа петелот се поистоветува со зората, сонцето и духовното препородување, се доживува како гласник на разденувањето, симбол на будењето и новиот ден (Vidović Bolt, 2011, 82).

Ова значење во македонската фразеологија се доловува со помош на следниве единици: први петли - 'околу полноќ'; полноќни петли 'многу доцна, во глуво доба на ноќта'; втори петли <nеат > - 'зора е'; петлина кова (арх.) - 'доцна ноќе кога пеат петлите'; петлена доба 'рано изутрина, во мугрите, на разденување'; петлени зори - 'рани зори, мугри'; кај петли време; пред петли време - 'рано изутрина, во мугрите, на разденување'. 
Во продолжение следат неколку контекстуални употреби на овие фраземи:

- Засилив коња, мале мајко ле, / [...] / дојдов дома, мале мајко ле, / в петлени доби, / порти си најдов, мале мајко ле, / се затворени (Димитровски, 1987, 96).

- Изутрина уште рано, кај петли време, дедот Петко стана, си го запали луленцето, си ја зеде торбичката со едно залавче лебец и ластегарката и тргна за Витолишча (Попов, 1980, 71).

- Пак стрина Маловица дојде. Мајката, таткото, и Митра на глуво доба, пред петли време, се собраа, повечераа од денешниот грашок и ја зедоа дуда од крошнето под оган (Попов, 1980, 121).

- Барем да пропеат петли, вели, да почне да се разденува (Андреевски, 1980, 103).

- Едно утро станувам порано [...] Петлите се петти, а уште не е доразденето (Андреевски, 1980, 101).

Само во една фразема (кога ќе ги стрижеме петлите) зоонимот петел се користи со друго значење, т.е. припаѓa на семантичкото поле никогаш.

Фраземите со значење 'никогаш, во никое време, под никакви околности' се изградени врз нереална или апсурдна слика. На пример, поимот подстрижување обично се врзува со овците, но во овие изрази се врзува со петли, со свиња и со мајмун: кога ќе ги стрижеме петлите, на свински стриг, кога ќе ги стрижат мајмуните. Во составот на овие фраземи влегуваат називи за домашни животни, но и за диви животни кои не се карактеристични за ова поднебје. Во овие фраземи на животните им се препишуваат несвојствени карактеристики или способности со што се постигнува алогичност и силна експресија (Vasung, 2011, 175). На пример, регистрираме невозможни трансформации од едно животно во друго (кога волкот беше куче/пес, кога ќе стане волкот куче), неостварливи промени на бојата на животното (кога ќе обели гавранот), несвојствени делови од телото (ако ја кажува змијата ногата, кога на коњот ке му пораснат рогови, кога ќе пушти коњот рогови), доделување на способност за гласовно изразување (кога ќе засвири риба летница). 
Мора да се напомне дека овие фраземи не се одликуваат со голема фреквентност во современиот македонски јазик, па затоа и примерите за нивната контекстуална употреба се извлечени од Речникот на македонска народна поезија и од опусот на Марко Цепенков.

- Ког’ќe засвирит риба летница, / риба летница по ирно море / ко 'ќе запеит камен станоит, / камен станоит на Никополе, / ти тога чедо ќе си добиеш! (Димитровски, 1987, 358).

- Ако кажуа змијата ногата, да и Евреин да каже крсто Христов (Димитровски, Ширилов, 2003, 384).

Прилогот засекогаш во Дигиталниот речник на македонскиот јазик ги има следниве толкувања 'за цел живот, за сите времиња, за навек’, а во зоонимниот фразеолошки материјал е застапен само во една единица: додека да обели гавранот. Сликата со промената на бојата на гавранот веќе беше спомената како невозможна и употребена за доловување на значење 'никогаш'. Овде со замена на сврзникот се добива ново значење, додека не се случи нешто што реално е неостварливо, т.е. 'за навек, засекогаш'.

Во продолжение нведуваме пример за употреба на оваа фразема: Помладиот брат: [...] Дури гавран не побелее, дури море не пресуши, дури гламја ластер не пушти, јас ќе бидам изар! (Димитровски, Ширилов, 2003, 140).

Во човековата претстава за светот секоја појава, секој процес и настан има посебно, определено време на случување. Нивната реализација во соодветното време води кон позитивен резултат, помага истите да се оставарат во полн потенцијал. Ако посакуваниот момент е замислен како норма, секој друг момент се смета за отстапување од нормата и не води кон очекуваниот резултат: или дошол премногу рано или премногу доцна.

Во анализираниот материјал дел од едниците кои имаат значење рано се поврзуваат со зоонимот кокошка. Кокошката е најраспространетото домашно животно, птица која е присутна во животот на човекот без оглед дали станува збор за урбана или рурална средина. Според тоа, сосема е разбирлива и очекувана нејзината застапеност во фразеолошкиот материјал. Овој зооним обично се употребува во негативна конотација и се користи за означување лица со ограничена интелектуална способност. Во нашиот материјал кокошката се поврзува со 
раното заминување на спиење и рано будење: си легнува со кокошките; легнува со кокошките, ама станува со петлите со значење 'рано легнува, рано станува', како и во станува со кокошките 'многу рано станува'. За сите фраземи наведуваме пример за нивна употреба (Димитровски, Ширилов, 2003-2009):

- Прокоп Трпков станува наутро заедно со петлите. Тој навик му е уште од дете, кога легнуваше со кокошките. Затоа подоцна, кога стана чирак, војник и работник, не му беше тешко без натегање да се одлепува од перницата.

- Какви ви се навиките? Да не легнувате со кокошките?Проитевајте за слободата. Се шегувам.

- Уите рано наутро, заедно со кокошките ќе станеше и Бапче и ке викнеше од скалите...

Уште еден зооним се јавува како компонента во фраземите со значење 'рано, пред време'. Станува збор за зоонимот зајак кој во Толковникот речник на македонскиот јазик (ТРМЈ, Конески, 2003-2014) се објаснува како плашливо диво животно од фамилијата глодачи со долги задни нозе и долги уши. Зајакот е честа компонента во фраземите и најчесто носи значење на плашливост, брзина и сл. Во нашиот материјал тој влегува во составот на фраземата уште е зајакот в шума. Овој израз најчесто се користи во ситуации кога се вели дека е прерано за радување.

Наредните зооними во анализираниот материјал се куче и пес. Кучето во Толковникот речник на македонскиот јазик (ТРМЈ, Конески, 2003-2014) се дефинира како: 1. 'домашно животно што лае и обично има улога на чувар'; 2. 'лош човек, крвник, проклетник'. Врската меѓу човекот и кучето е веројатно најстарата и најблиската врска со некое животно. Често се вели дека кучето е најдобриот и најверниот пријател на човекот, додека на мачката и се припишуваат неискреност и пресметлив карактер. Човекот го користи кучето за лов, за влечење, за чување на имотот и стадата, за помош на инвалиди, полициски задачи и др. (Visković, 2009, 271-273). Овој зооним обично се користи како компонента во фраземи со значење 'верност, лоши услови за живот, глад, исцрпеност’ и слично. Во нашиот материјал формата кучка е употребена во фраземата колку што се врти кучка на трло и има значење 'многу кратко време', а формата куче, 
пак, се користи во фраземи кои означуваат лоши метеоролошки услови. Тоа го регистрираме во фраземите: кучешко време; куче да врзеш, ќе иркне и кучето и мачето спијат заедно со значење 'многу студено време'. Според истиот модел е изградена и фраземата глувче и маче спијат заедно. Познато е дека кучето и мачето обично не се сложуваат најдобро, а глувчето и мачето се вечни непријатели. Нивното спојување и заедничко спиење значи дека условите се толку многу лоши, дека времето е толку многу студено, што заборавиле на меѓусебното непријателство. Во наредниот пример се гледа употребата на фраземата куче да врзеш ќе цркне каде дополнително и од контекстот се добива информација за крајно студеното време на кое не би издржале ни кучињата.Тихон рече, седни човеку, седни огреј се, надвор времето е, куче да врзеш ќе цркне (Димитровски, Ширилов, 2008, 109).

Спротивно на ова, уживањето на жешко време се поврзува со зоонимот гуштер. Влечугата со четири нозе и со долга опашка која се храни со инсекти е позната и по преферирање на сончево и жешко време. Оваа негова карактеристика изразена е во фраземата се сонча <се пече> како гуштер (на камен). Откако се сместија, отидоа во кабините да се пресоблечат и кога се вратија Марко им рече: - Овде ќе се печеме како гуштери (Димитровски, Ширилов, 2003, 231).

Последниот зооним кој го обработуваме во овој труд е меч$\kappa a$. Овој зооним е составен дел на фраземата мечка се жени која се користи за означување на ситуација кога истовремено врне дожд и грее сонце. Дождот и облаците се во директна опозиција со сонцето и нивното истовремено појавување претставува природната аномалија. Оваа неприродна состојба во природата се поврзува со неприроден сојуз кај животните. Тоа не е национална особеност на македонскиот јазик, туку се работи за древно опишување на аномалиите кое се среќава кај голем број народи. Така, во македонскиот јазик велиме дека мечка се жени, во францускиот - волци се женат, во грчкиот - магариња, во унгарскиот - волци, во јапонскиот - лисици, во англискиот - мајмуни итн.: Во скопската населба Ново Лисиче во моментов има пороен дожд проследен со соние или помеѓу народот познато како феномент „мечка се жени“ (Истура дожд: „Мечка се жени“ во Ново Лисиче). 


\section{5. Заклучок}

Во овој труд беше анализиран сосема мал сегмент од македонската фразеологија, но дури и овој малуброен корпус покажа дека зоонимните фраземи даваат експресивна и сликовита претстава за голем број поими, меѓу кои и една универзална категорија каква што е времето.

Во формирањето на значењето на овие единици зоонимот игра исклучително важна улога. Во анализираниот материјал беа застапени 13 животни карактеристични за ова поднебје (со исклучок на мајмунот) кои човекот добро ги познава. Искуството и присутноста на животните во животот на човекот, доброто познавање на нивните основните карактеристики, однесувањето и начинот на живот претставуваат одлично тло за нивна употреба и непосредна мотивација за образување на овие единици. Ова е сосема разбирливо, особено ако го имаме предвид фактот дека човекот секогаш посегнува по нешто што му е добро познато во обид да го разбере она му далечно и апстрактно.

Она што ги издвојува анализираните единици од останатиот фразеолошки материјал со зоонимни компоненти е нивната релативна неутралност имајќи предвид дека генерално зоонимните фраземи се негативно обоени. Ваквата неутралност од една страна се должи на нивната семантика, а од друга страна на тоа што во нив се прикажани особините и начините на однесување на животните онакви какви што се во реалноста.

\section{Литература}

Алчевска, И. (2016). Фраземи со компоненти на зооними во рускиот и во македонскиот јазик. Во: Меѓународна научна конференција „Зборот збор отво$p a “$ Ур. Б. Мирчевска-Бошева. Скопје: Филолошки факултет „Блаже Конески“, стр. 73-86.

Арутюнова, Н. Д. (1997). Время: модели и метафоры. Во: Логический анализ языка. Язык $и$ время. Отв. ред. Н.Д. Арутюнова, Т.Е. Янко. Москва: Индрик, стр. $51-61$.

Велјановска, К. (2014). Анализа на македонските и на хрватските зоонимни фраземи со соматска компонента. Bo: Životinje u frazeološkom ruhu. Ur. I. Vidović Bolt. Zagreb: FF press Filozofskoga fakulteta Sveučilišta u Zagrebu. 
Кузмановска, Д., Петковска, Б. (2013). Именските фразеологизми со компонентата зооними разгледувани во македонскиот, германскиот и англискиот јазик. „Годишен зборник“ бр. 3 (3), стр. 151-156.

Макаријоска, Л., Павлеска-Георгиевска, Б. (2020). Фраземи со зооними во медиумска употреба. Во: Прилози за македонската фразеологија. Скопје: Л. Макаријоска, Б. Павлеска-Георгиевска, стр. 180-204.

Мелерович, А. М. (1979). Проблема семантического анализа фразеологических единиц современного русского языка. Ярославль: Ярославский педагогический институт.

Мирчевска-Бошева, Б. (2009). Времето и јазикот. „Славистички студии“ бр. 13, стр. 201-211.

Новокмет, С. (2016). Семантичка анализа лексема које означавају животиње y савременом српском језику. [Докторска дисертација]. Београд: Филолошки факултет Универзитета у Београду. https://nardus.mpn.gov.rs/bitstream/ handle/123456789/6693/Disertacija4763.pdf? sequence $=6 \&$ is Allowed=y. 9.09.2020.

Телия, В. Н. (1986). Коннотативный аспект семантики номинативных единиц. Москва: Наука.

Толстой, Н. И. (1997). Времени магический круг (по представлениям славян). Во: Логический анализ языка. Язык и время. Отв. ред. Н. Д. Арутюнова, Т. Е. Янко. Москва: Индрик, стр. 17-27.

Томоска, М. (2015). Фразеолошките изрази со компонента зооним во макеоднскиот јазик. [Необјавена магистерска дисертација]. Скопје: Филолошки факултет „Блаже Конески“.

Яковлева, Е. С. (1994). Фрагменты русской языковой картины мира (модели пространства, времени и восприятия). Москва: Гнозис.

[Alchevska, I. (2016). Frazemi so komponenti na zoonimite vo ruskiot $i$ vo makedonskiot jazik. Vo: Megjunarodna nauchna konferencija "Zborot zbor otvora“. Ur. B. Mirchevska-Bosheva. Skopje: Filoloshki fakultet „Blazhe Koneski“, str. 73-86.

Arutjunova, N. D. (1997). Vremja: modeli i metafory. Vo: Logicheskij analiz jazyka. Jazyk i vremja. Otv. red. N. D. Arutjunova, T. E. Janko. Moskva: Indrik, str. 51-61.

Veljanovska, K. (2014). Analiza na makedonskite i na hrvatskite zoonimni frazemi so somatska komponenta. Vo: Životinje u frazeološkom ruhu. Ur. I. Vidović Bolt. Zagreb: FF Press Filozofskoga fakulteta Sveučilišta u Zagrebu.

Kuzmanovska, D., Petkovska, B. (2013). Imenski frazeologizmi so komponenta zoonimi razgleduvani vo makedonskiot, germanikot i angliskiot jazik. „Godishen zbornik“ br. 3 (3), str. 151-156.

Ljubičić, M. (1994). O hrvatskim zoonimima: konotativno značenje i frazeologija. „Filologija" br. 22-23, str. 245-252.

Makarioska, L. Pavleska-Georgievska, B. (2020). Frazemi so zoonimi vo mediumska upotreba. Vo: Prilozi za makedonskata frazeologija. Skopje: L. Makarioska, B. Pavleska-Georgievska, str. 180-204. 
Melerovich, A. M. (1979). Problema semanticheskogo analiza frazeologicheskih jedinic sovremennogo russkogo jazyka. Jaroslavlj: Jaroslavskij gosudarstvennyj pedagogicheskij institut.

Mirchevska-Bosheva, B. (2009). Vremeto i jazikot. „Slavistichki studii“ br. 13, str. 201-211.

Novokmet, S. (2016). Semantička analiza leksema koje označavaju životinje u savremenom jeziku. [Doktorska disertacija]. Beograd: Filološki fakultet Univerziteta u Beogradu. https://nardus.mpn.gov.rs/bitstream/handle/123456789/6693/Disertacija 4763.pdf? sequence $=6 \&$ isAllowed $=$ y. 9.09.2020.

Telija, V. N. (1986). Konnotativnyj aspekt semantiki nominativnyh jedinic. Moskva: Nauka.

Tolstoj, N. I. (1997). Vremeni magicheskij krug (po predstavlenijam slavjan). Vo: Logicheskij analiz jazyka. Jazyk i vremja. Otv. red. N. D. Arutyunova, T. E. Janko. Moskva: Indrik, str. 17-27.

Tomoska, M. (2015). Frazeoloshkite izrazi so komponenta zoonim vo makedonskiot ja$z i k$. [Neobjavena magisterska teza]. Skopje: Filoloshki fakultet „Blazhe Koneski“.

Jakovleva, E. S. (1994). Fragmenty russkoj jazykovoj kartiny mira (modeli prostranstva, vremeni i vosprijatija). Moskva: Gnozis].

Pamies, A. (2012). Zoo-symbolism and metaphoric competence. Vo: Focal Issues on Phraseological Studies. Eds. J. Szerszunowicz, K. Yagi. Białystok-Osaka: University of Białystok-Kwansei Gakuin University, str. 291-314.

Vasung, A. (2011). Frazemi sa značenjem nikada u bugarskom, hrvatskom, makedonskom i srpskom jeziku. „Филолошки студии“ t. 9, br. 1, str. 167-178.

Vidović Bolt, I. (2011). Životinjski svijet u hrvatskoj i poljskoj frazeologiji. Zagreb: Hrvatska sveučilišna naklada.

Vidović Bolt, I. (2014). Životinja kao (ne)inteligentni čovjekov prijatelj. Vo: Zbornik radova s međunarodnog znanstvenog skupa Animalistički frazemi u slavenskim jezicima Životinje u frazeološkom ruhu. Ur. I. Vidović Bolt. Zagreb: Filozofski fakultet sveučilišta u Zagrebu, str. 1-12. http://www.animalistickifrazemi.eu/images/frazemi/zbornik_radova/Vidovic_Bolt\%20za\%20WEB.pdf, 7.09.2020-21.10.2020.

Visković, N. (2009). Kulturna zoologija. Zagreb: Naklada Jesenski i Turk.

\section{Извори}

Андреевски, П. (1980). Пиреј. Скопје: Мисла.

Велковска, С. (2008). Македонска фразеологија со мал фразеолошки речник. Скопје: авторско издание.

Дигитален речник на македонскиот јазик. http://drmj.eu/. 7.09.2020-20.10.2020.

Димитровски, Т. (ур.). (1983-1993). Речник на македонската народна поезија. Скопје: Институт за македонски јазик „Крсте Мисирков“. 
Димитровски, Т., Ширилов, Т. (2003-2009). Фразеолошки речник на македонскиот јазик. Скопје: Огледало.

Истура дожд: „,Мечка се жени“ во Ново Лисиче. „Вечер“, 11.06.2019, https://dev. vecer.mk/node/20412. 8.10.2020.

Конески, К. (ред.). (2003-2014). Толковен речник на македонскиот јазик. Скопје: Институт за македонски јазик „Крсте Мисирков“.

Попов, С. (1980). Крпен живот. Скопје: Мисла.

[Andreevski, P. (1980). Pirej. Skopje: Misla.

Velkovska, S. (2008). Makedonska frazeologija so mal frazeoloshki rechnik. Skopje: avtorsko izdanie.

Digitalen rechnik na makedonskiot jazik. http://drmj.eu/. 7.09.2020-20.10.2020.

Dimitrovski, T. (ured.) (1983-1993). Rechnik na makedonska narodna poezija. Skopje: Institut za makedonski jazik „Krste Misirkov“.

Dimitrovski, T., Shirilov, T., (2003-2009). Frazeoloshki rechnik na makedonskiot jazik. Skopje: Ogledalo.

Istura dozhd: „Mechka se zeni” vo Novo Lisiche. „Vecher“ 11.06.2019, www.vecer. mk. 8.10.2020.

Koneski, K. (red.) (2003-2014). Tolkoven rechnik na makedonskiot jazik. Skopje: Institut za makedonski jazik „Krste Misirkov”.

Popov, S. (1980). Krpen zivot. Skopje: Misla]. 